\title{
Prevalence, Plasmids and Antibiotic Resistance Correlation of Enteric Bacteria in Different Drinking Water Resources in Sohag, Egypt
}

\author{
Khalid Abdalla Ali AbdelRahim ${ }^{1,2, *}$; Ahmed Mohamed Hassanein ${ }^{2}$; Heikal Abd El Hakim \\ Abd El Azeiz ${ }^{2}$ \\ ${ }^{1}$ Department of Botany and Microbiology, King Saud University, Riyadh, Saudi Arabia \\ ${ }^{2}$ Department of Botany, Sohag University, Sohag, Egypt \\ ${ }^{*}$ Corresponding author: Khalid Abdalla Ali Abdel Rahim, Department of Botany and Microbiology, King Saud University, P. O. Box: 2455, Riyadh, Saudi Arabia. Tel: +96-6114675818, Fax: \\ +96-6114675833, E-mail: khalidfp7@gmail.com
}

Received: March 1, 2014; Revised: June 29, 2014; Accepted: August 4, 2014

\begin{abstract}
Background: One of the major health causing problems is contamination of drinking water sources with human pathogenic bacteria. Enteric bacteria such as Shigella, Salmonella and Escherichia coli are most enteric bacteria causing serious health problems. Occurrence of such bacteria infection, which may resist antibiotics, increases the seriousness of problem.

Objectives: The aim of this study was to examine the prevalence of some enteric bacteria (Shigella, Salmonella and E. coli) in addition to Pseudomonas. The antibiotic susceptibility of these bacteria was also tested, in addition to assessing plasmid(s) roles in supposed resistance. MRSA genes in non-staphylococci were clarified.

Materials and Methods: Water samples were collected from different drinking sources (Nile, ground water) and treated tap water. Selective media were used to isolate enteric bacteria and Pseudomonas. These bacteria were identified, counted and examined for its susceptibility against 10 antibiotics. The plasmids were screened in these strains. MRSA genes were also examined using PCR.

Results: Thirty-two bacterial strains were isolated from Nile and ground water and identified as S. flexneri, S. sonnei, S. serovar Newport, Pseudomonas aeruginos $a$ and E. coli strains according to standard methods. According to antibiotic susceptibility test, $81 \%$ of strains were resistant to Cefepime, whereas $93.75 \%$ were sensitive to Ciprofloxacin. Correlation analysis between plasmids profiles and antibiotics sensitivities showed that $50 \%$ of the total strains had plasmids. These strains showed resistance to $50 \%$ of the used antibiotics (as average value); whereas, the plasmids free strains (50\%) were resistant to $48.7 \%$ of the antibiotics. No distinct correlation between plasmids and antibiotic resistance in some strains could be concluded in this study. No MRSA gene was detected among these non-staphylococci strains. No bacteria were isolated from treated tap water.

Conclusions: Thirty-three bacterial strains; 10 strains of E. coli, 10 strains of S. flexneri, 3 strains S. sonnei, 2 strains of S. serovar Newport, and 7 strains of $P$. aeruginosa, were isolated and identified from Nile water and ground water in Sohag governorate. The prevalence of enteric bacteria in water sources in studying area was considerable. No clear or distinct correlation could be concluded between plasmids and antibiotic resistance. No MRSA gene was detected in these non-staphylococci strains, and no pathogenic bacteria were isolated from treated tap water. The hygiene procedures in the studying area seem to be adequate, despite the failure to maintain water sources form sewage pollution.
\end{abstract}

Keywords:Water; Methicillin-Resistant Staphylococcus aureus; Antibiotics; Plasmid

\section{Background}

Antibiotic resistance emergence in pathogenic bacteria in each of hospital and community as well, represents a significant public health problem (1-4). Inheritance of this phenomenon in bacteria is controlled by either chromosome or plasmid according to many studies. Bacterial cells are able to transfer genes horizontally, which can occur in three ways; through plasmids, phages, or uptake of naked DNA "transformation" (5). Plasmids as extra-chromosomal pieces of DNA are capable to replicate independently of the genome. Plasmids have a considerable role in resistance to many antibiotics and in spreading of antibiotic resistance genes (6-12). These cause serious problems, since plasmids can cross many species and genus barriers, which allow resistance to spread and persist in organisms not necessarily subject to antibiotics (13).

The antibiotics resistant bacteria were isolated, not only from environments contaminated with antimicrobial agents, e.g. hospitals, fish farms, sewage effluents, and wastewater (14), but also from apparently nonselective environments (15). Kruse and Sorum (14) reported that environmental contamination with resistant bacterial pathogens is a real threat, not only as a source of disease, but also as a source from which plasmids can easily spread to other pathogens. Methicillin is a semisynthetic derivative of penicillin. It was first produced in the late 1950s and developed as a type of antibiotic called a penicillinase-resistant penicillin. It contained a modification

Copyright (C) 2015, Ahvaz Jundishapur University of Medical Sciences. This is an open-access article distributed under the terms of the Creative Commons Attribution-NonCommercial 4.0 International License (http://creativecommons.org/licenses/by-nc/4.0/) which permits copy and redistribute the material just in noncommercial usages, provided the original work is properly cited. 
to the original penicillin structure made it resistant to a bacterial enzyme called penicillinase (beta-lactamase). Methicillin-resistant Staphylococcus aureus (MRSA) is one of the most important hospital associated (nosocomial) bacterial pathogens worldwide. Detection of methicillin resistance among Staphylococcus isolates is based on phenotypic assays, until that confirmed genetically based on the detection of mecA gene (16), that associated with methicillin resistance $S$. aureus (17).

\section{Objectives}

The performance of mecA gene detection in non-staphylococci bacteria was examined, to clarify if it gained this gene (mecA gene) through plasmid, phage, or transformation processes, or it (mecA gene) may correlated only to $S$. aureus strains.

\section{Materials and Methods}

\subsection{Sample Collection}

Two sampling campaigns were conducted in October 2011 and March 2012 to collect 18, 26 and 26 water samples from river Nile, treated raw water and groundwater respectively from seven locations (Tema, Tahta, Sakolta, Sohag, Akhmim, Girga, Dar-Elsalam) along Sohag governorate. Samples were transported in icebox to the laboratory, and microbiological determinations were performed within six hours.

\subsection{Bacteria}

Thirty two strains were isolated from referred different water resources in Sohag governorate, Egypt and identified according to Bergey's Manual, 1989 (18). For determination of total bacterial count, serial diluted samples were grown on standard method agar (P. C. A) Acc.to APHA and ISO 4833, while Pseudomonas isolation agar medium was used for isolation of Pseudomonas aeruginosa (19). M-Endo Agar LES (Difco, USA) according to Tajima et al. (20), standard methods for examination of water and waste water were used for enumeration of total coliforms in water by membrane filter technique. Lauryl tryptose broth (Difco, USA) was used for verification of total coliforms. MFC Agar Base was used with Rosolic Acid in cultivating and enumerating fecal coliforms by the membrane filter technique. Azide dextrose broth medium was used for counting fecal streptococci (20). Aesculin Azide Agar was used for verification of fecal streptococci, and Escherichia coli was counted on MacConkey agar medium after incubation at $44^{\circ} \mathrm{C}$ for 48 hours. X.L.D Agar medium was used as selective medium for isolation of Salmonella spp., Shigella spp. and incubated for 24 hours at $37^{\circ} \mathrm{C}$ (ISO, 1978). S. aureus strain was selected and used as standard for MecA gene screening.

\subsection{Antibiotics Susceptibility}

All isolates of Salmonella, Shigella, Pseudomonas and E. coli were tested for susceptibility against the following antibiotics: amoxicillin/clavulanic acid (30 $\mu \mathrm{g})$, Rifamycin (30 mcg), Cefalexin (30 mcg), Erythromycin (15 mcg), Ceftazidim (30 mcg), Norfloxacin $(10 \mu \mathrm{g})$, Ciprofloxacin (5 $\mu \mathrm{g})$, Cefepime (30 mcg), Ertapenem (10 $\mu \mathrm{g})$ and Cefoxitin (30 mcg), by the Bauer's disk diffusion method (21).

\subsection{DNA Extraction}

Genomic DNA was extracted according to Maloy, (22), whereas plasmids DNA were extracted according to Birnboim, (23).

\subsection{Amplification for mecA Gene}

The method was performed according to Towner et al. (24). DNA samples were diluted to concentration of 20 $\mathrm{ng} / \mu \mathrm{L}$ prior to amplification. Five $\mu \mathrm{L}$ aliquot of bacterial genomic DNA was combined with $12.5 \mu \mathrm{L}$ of master mix $\left(500 \mathrm{mM} \mathrm{KCl}, 100 \mathrm{mM}\right.$ tris- $\mathrm{HCl}\left(\mathrm{pH}\right.$ at $\left.25^{\circ} \mathrm{C}\right), 15 \mathrm{Mm} \mathrm{MgCl}_{2}$, $1 \%$ Triton X-100), $1 \mu \mathrm{L}$ of a deoxynucleoside triphosphate (dNTP) mixture (concentration of dNTP, $5 \mathrm{mM}$ ), and 2 $\mu \mathrm{L}$ each of two 15-base oligonucleotide primers (primer MecA1 and MecA2 (concentration, $50 \mathrm{ng} / \mu \mathrm{L}$ )) $3.5 \mu \mathrm{L}$ deionized water; the final volume was $25 \mu \mathrm{L}$.

\subsection{Primers}

\section{MecA1 (5'-GTA GAA ATG ACT GAA CGT CCG ATA A) \\ MecA2 (5'-CCA ATT CCA CAT TGT TTC GGT CTA A)}

The PCR cycling conditions were as follows: initial denaturation at $94^{\circ} \mathrm{C}$ for 4 minutes, followed by 30 cycles of 45 seconds at $94^{\circ} \mathrm{C}, 45$ seconds at $50^{\circ} \mathrm{C}$, and 60 seconds at $72^{\circ} \mathrm{C}$ with the final extension step at $72^{\circ} \mathrm{C}$ for two minutes. Tenmicroliter was loaded onto agarose gel electrophoresis.

\section{Results}

\subsection{Bacteria}

As shown in Table 1, 32 bacteria were isolated from Nile and ground water. These strains were identified by means of standard procedures described in the Bergey's manual of systematic microbiology and standard laboratory procedures. Ten strains of E. coli, 10 strains of Shigella flexneri, 3 strains of S. sonnei, 2 strains of Salmonella serovar Newport, and 7 strains of $P$. aeruginosa were detected. No pathogenic bacteria were isolated from treated tap water.

\subsection{Antibiotics Susceptibility}

As shown in Figure 1, most of strains (81\%) were resistant to Cefepime, whereas two strains only (6.25\%) were resistant to Ciprofloxacin, one belonged to S. flexneri and the other to S. sonnei.

\subsection{Salmonella serovar Newport}

Two isolates were identified as S. serovar Newport. These 
strains were resistant to $40-50 \%$ of used antibiotics. The strain AB2 was resistant to $40 \%$ of antibiotics and isolated from Nile water in Akhmim region. This strain did not possess any plasmids. Strain AB1 possessed four plasmids and were resistant to Cefepime as an extra antibiotic, which inhibits the growth of the other strain, AB2 (Table 1). According to the results listed in Table 1, 50\% (1 of 2) of the strains possessed plasmids (Figure 2), with resistance to about $50 \%$ of the used antibiotics, whereas the plasmids free strains were resistant to $40 \%$ of the antibiotics.

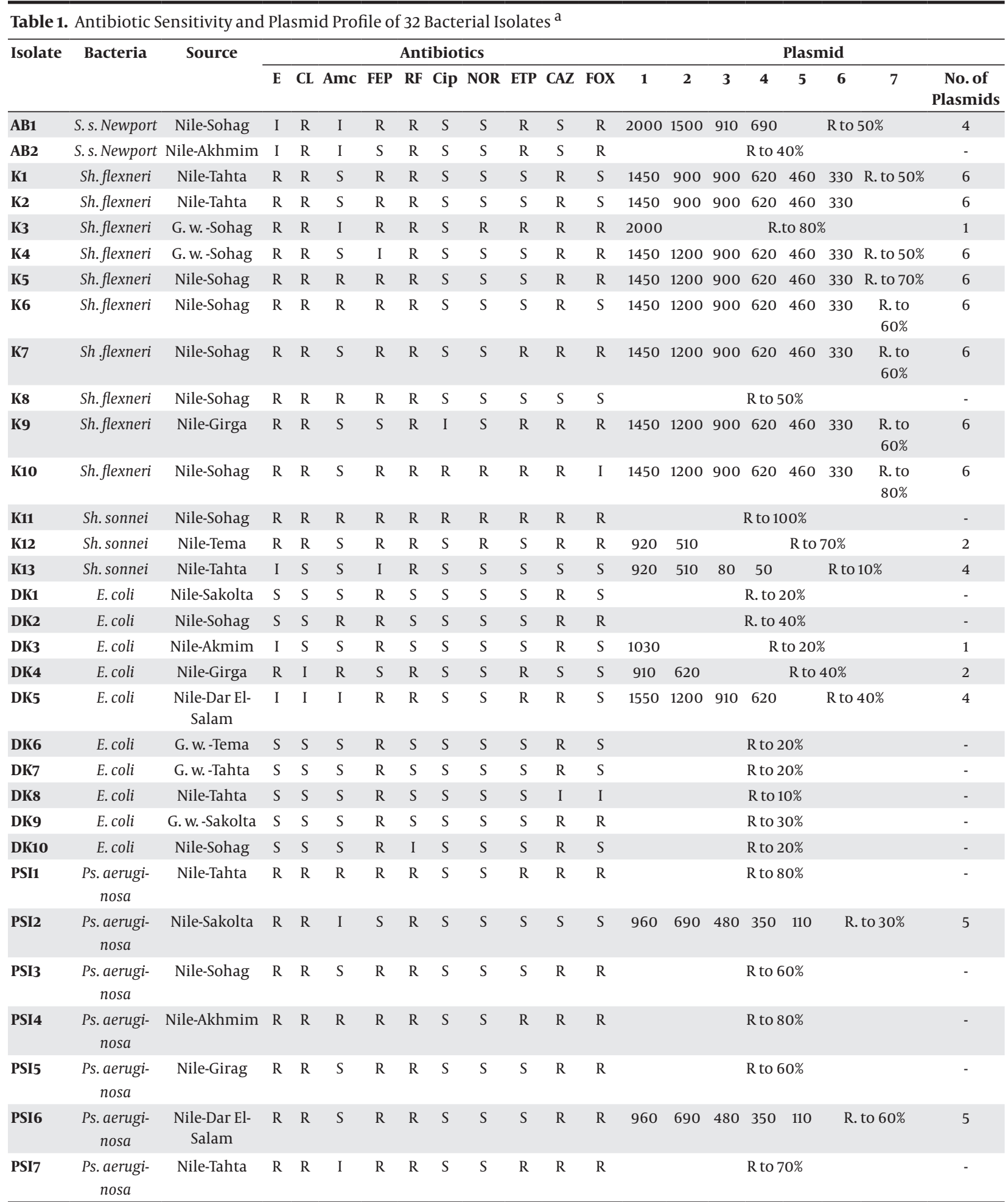

\footnotetext{
a Abbreviations: Amc, amoxicillin/clavulanic acid; CAZ, ceftazidime; CIP, ciprofloxacin; CL, cephalexin; E, erythromycin; ETP, ertapenem; FEP, Cefepime; FOX, cefoxitin; I, intermediate; NOR, norfloxacin; R, resistant; RF, rifamycin; S, sensitive.
} 
Figure 1. Percent of Resistant Strains Against Antibiotics

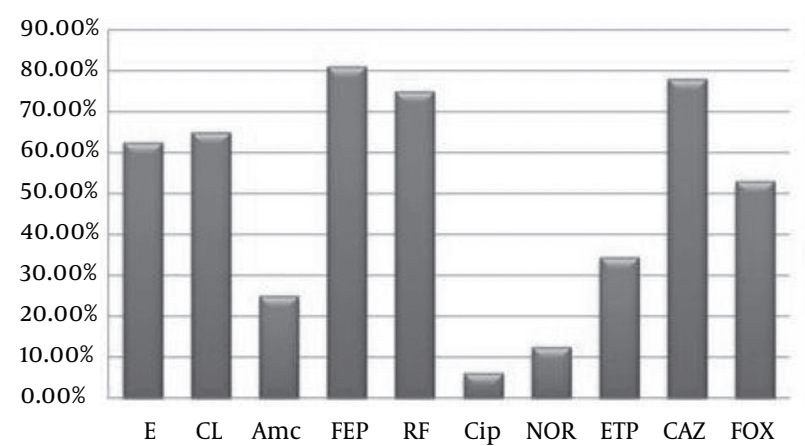

Amc, amoxicillin/clavulanic acid; CAZ, ceftazidime; CIP, ciprofloxacin; CL cephalexin; E, erythromycin; ETP, ertapenem; FEP, Cefepime; FOX, cefoxitin; NOR, norfloxacin; RF, rifamycin.

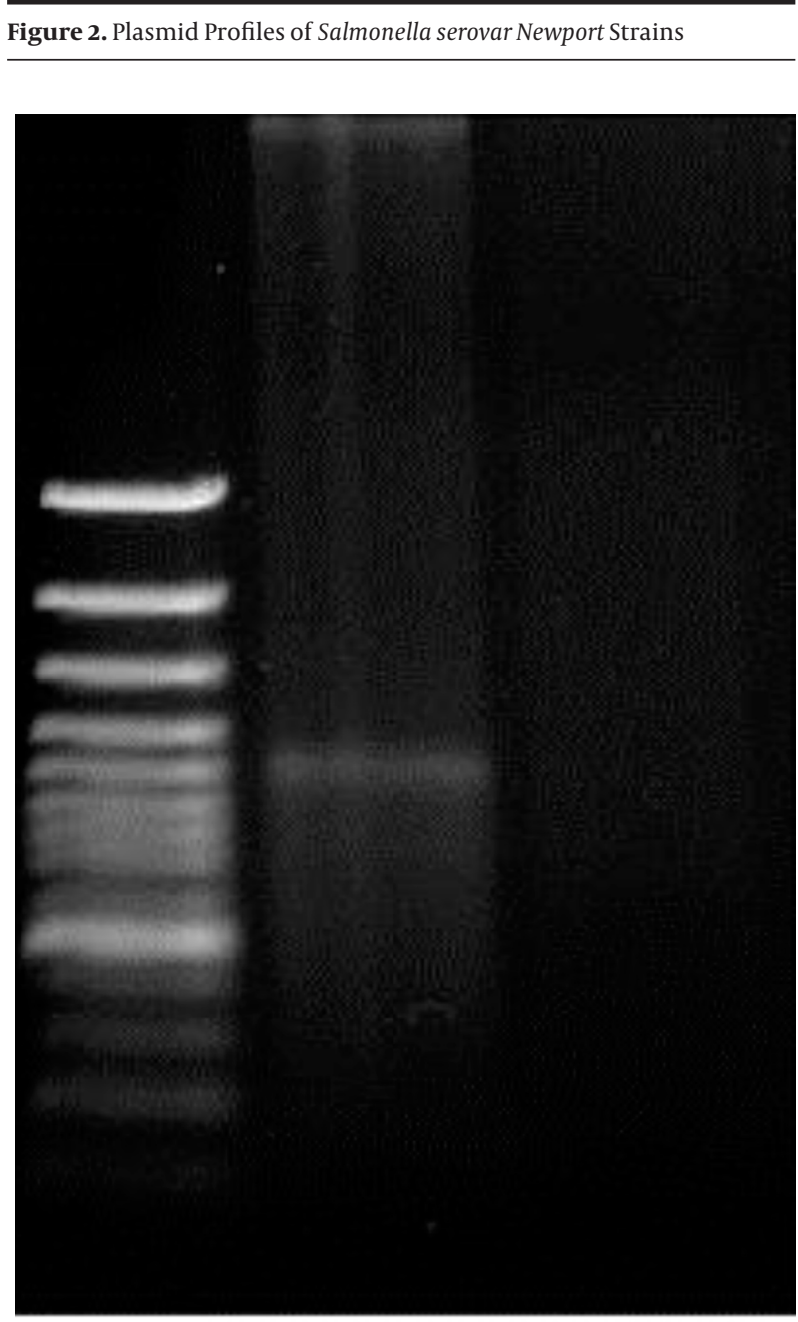

M

M, marker; lane 1, Strain AB2; lane 2, Strain AB1.

\subsection{Shigella flexneri}

Ten isolates were identified as S. flexneri. These strains were resistant to $50-80 \%$ of appropriate antibiotics. The strain $\mathrm{K} 8$, isolated from Nile water, was resistant to $50 \%$ of used antibiotics, but did not possess any plasmids. Strain $\mathrm{K} 3$, isolated from ground water was resistant to $80 \%$ of the antibiotics; possessed one plasmid of $2000 \mathrm{bp}$ (Table 1, Figure 3). As listed in Table 1, 90\% (9 of 10) of the strains possessed plasmid(s), with resistance to about $62.2 \%$ of the used antibiotics. The plasmids free strains were resistant to $50 \%$ of used antibiotics (Figure 4 ).

\subsection{Shigella sonnei}

Three isolates were identified as S. sonnei. The strain (K11) resistant to $100 \%$ of used antibiotics, was isolated from Nile water at Sohag, but did not possess any plasmids, whereas the strain K13 which isolated from Nile water at

Figure 3. Plasmid Profiles of Shigella sonnei

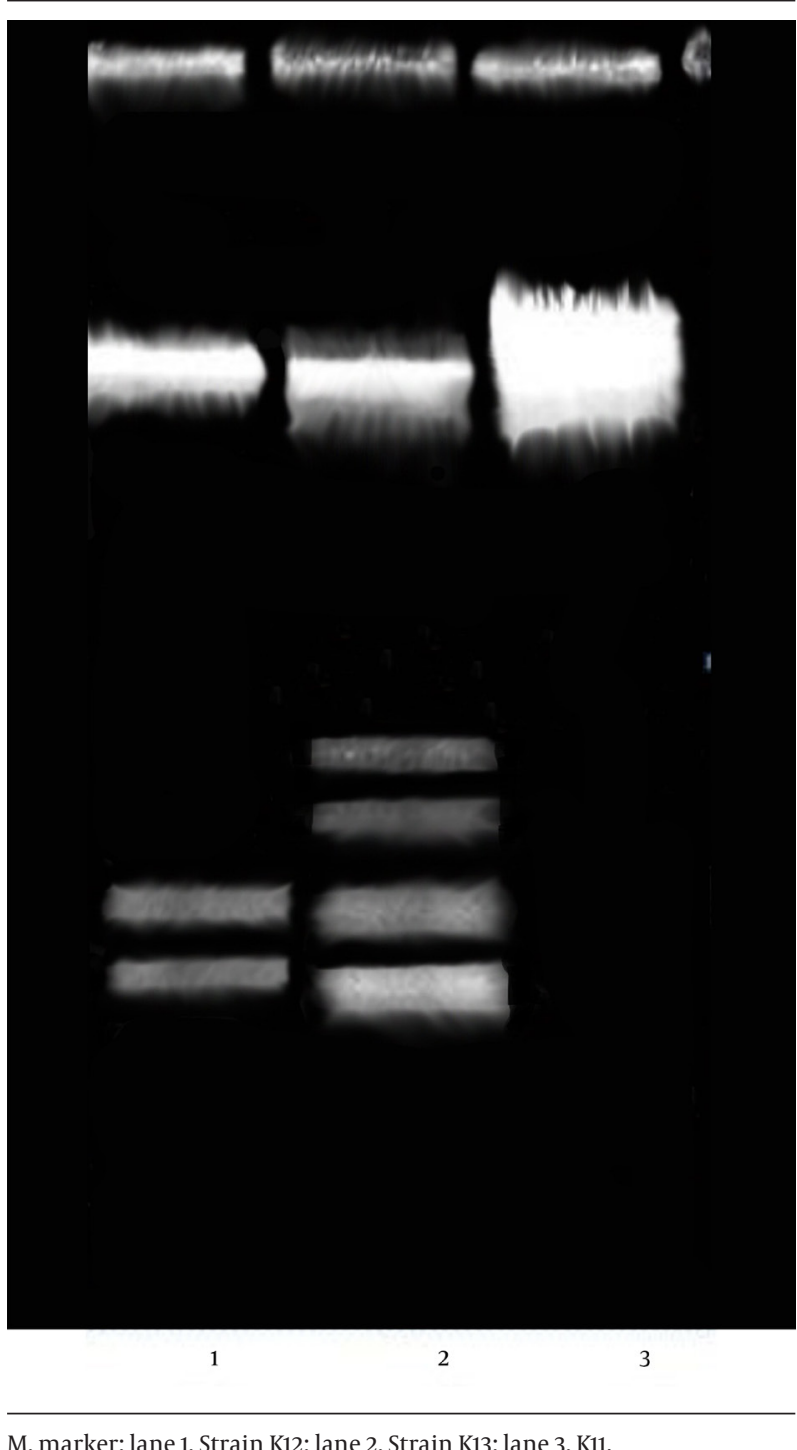

M, marker; lane 1, Strain K12; lane 2, Strain K13; lane 3, K11. 


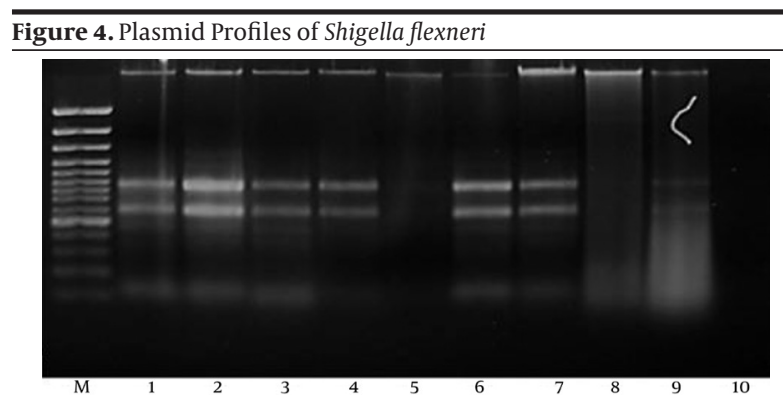

M, marker; lane 1, Strain K1; lane 2, Strain K2; lane 3, K3; lane 4, K4; lane 5, K5; lane 6, K6; lane 7, K7; lane 8, K9; lane 9, K9; lane 10, strain K8.

Resistance avarage
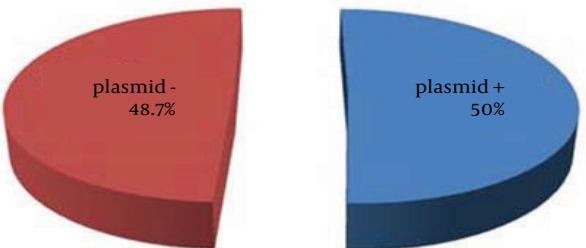

Figure 5. Correlation Between Antibiotics Resistance Average and Plasmids Presence in 32 Different Strains

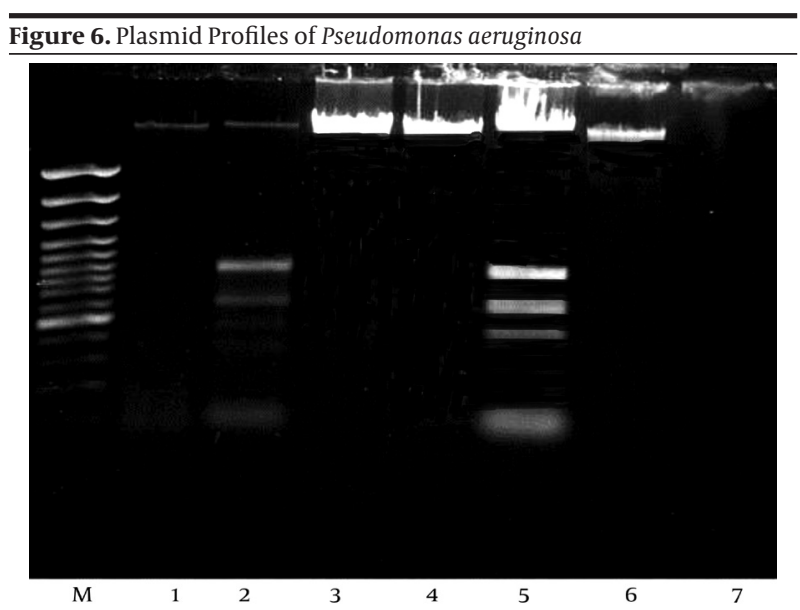

M, marker; lane 1, Strain PS11; lane 2, Strain PS12; lane 3, PS13; lane 4, PS14; lane 5, PS16; lane 6, PS15; lane 7, PS17.

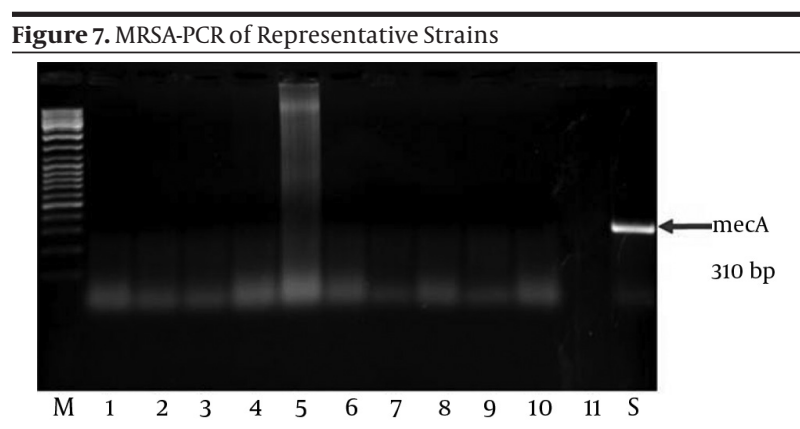

M. DNA size marker; lane 1-3, E. coli ; lane 4-6, Shigella flexneri; lane 7-8, Pseudomonas aeruginosa; lane 9, Shigella sonnei; lane 10, Salmonella serovar Newport; lane 11, negative control; lane S, MRSA-positive control with the 310 bp mecA.
Tahta, was resistant to $10 \%$ (Cefepime) of the antibiotics, although it possessed four plasmids (Table 1, Figure 5). Strain K12 was also resistant to most of antibiotics (70\%), although it had two plasmids (Table 1). In total, 66.6\% (2 of 3 ) of S. sonnei strains included plasmids (Figure 3). These strains were resistant to $40 \%$ of the used antibiotics, whereas the plasmids free strains were resistant to $100 \%$ of the antibiotics.

\subsection{Escherichia coli}

Most sensitive strains were belonged to E. coli strains, since $10-40 \%$ were resistant to antibiotics. Seventy percent $(70 \%)$ of the E. coli strains $(\mathrm{n}=10)$ were plasmids free strains. The strain DK5 possessed four plasmids and resistant to $40 \%$ of the antibiotics, strain DK4 was resistant to $40 \%$ of used antibiotics, DK3 was resistant to $20 \%$ of antibiotics and possessed two, and one plasmids, respectively (Table 1). According to the results listed in Table 1, 30\% (3 of 10) of the strains possessed plasmids, with resistance to $33.3 \%$ of the used antibiotics, whereas the plasmids free strains were resistant to $22.8 \%$ of the antibiotics.

\subsection{Pseudomonas aeruginosa}

The strains resistant to $60-70 \%$ of the antibiotics (PS 11, PS13, PS 14, PS 15, PS 17), possessed no plasmids. Two strains (PS12, PS16) were identical in plasmid profile (5 plasmids), although the first strain was resistant to $30 \%$ of the antibiotics and the second strain (PS 16) to 60\% of the antibiotics (Table 1). As listed in Table 1, 28.5\% (2 of 7) of $P$. aeruginosa strains possessed plasmids (Figure 6). These plasmids including strains were resistant to $45 \%$ of the used antibiotics, whereas the others plasmids free $P$. aeruginosa strains were resistant to $70 \%$ of the antibiotics. According to the results listed in Table 1, 50\% (16 of 32) of the total strains had plasmids. These strains showed resistance to $50 \%$ of the used antibiotics (as average value); whereas, the plasmids free strains (50\%) were resistant to $48.7 \%$ of the antibiotics (Figure 5). From the results of this study, we can conclude no distinct correlation between plasmids and antibiotic resistance.

\subsection{Detection of MRSA Gen by PCR Amplification}

Methicillin-resistant gene was undetected (negative) in E. coli, Salmonella spp., Shigella spp. and Pseudomonas sp. as shown in Figure 7.

\section{Discussion}

Resistance to antibiotic is a worldwide problem. Health leaders in the world consider antibiotic-resistant bacteria as "nightmare bacteria" that "pose a catastrophic threat" to people worldwide. Among all bacterial resistance problems, Gram-negative pathogens are particularly worrisome, because they are becoming resistant to nearly all drugs considered for treatment (25). The most serious Gram-negative infections are healthcare-associat- 
ed, and the most common pathogens are Enterobacteriaceae, $P$. aeruginosa and Acinetobacter. Treating infections of either pan-resistant or nearly pan-resistant Gram-negative microorganisms is an increasingly common challenge in many hospitals (26). The relatively high level of antibiotics resistance in pathogenic bacteria is due to the misuse of these antibiotics during treatment of bacterial infections. Hsu et al. (27) reported that differences in bacterial resistance to various antibiotics might reflect the history of antibiotic applications. Plasmid is one of the most important mediators in facilitating fast spreading of antibiotic resistance among bacteria (28).

Our results revealed that plasmid profiles differed considerably, even in the strains belonging to the same species. For example, resistance of $S$. serovar Newport strain AB1 to Cefepime is correlated to presence of four plasmids (Table 1, Figure 4), unlike the plasmid free strain AB2. Both of strains were resistant to the same antibiotics used in this study, although isolated from the same water source (Nile water), but different regions (Table 1). This finding assumes that there is a distinct correlation between these plasmids and resistance to antibiotics.

The strain of S. flexneri, K3 showed a unique plasmid profile (one plasmid of $2000 \mathrm{bp}$ ). There is no distinct correlation between plasmids and antibiotic resistance in this bacteria, since we found strains which did not possess any plasmids (strain K8), but resistant to the same antibiotics, been resistant by plasmid(s) including strains (strains K1, K2, K4) (Table 1, Figure 6). Three S. sonnei strains had different plasmid profiles. Regarding three $S$. sonnei strains, the more plasmid present in the bacteria, the less antibiotics resistance was found. In Table 1 and Figure 7, strain S. sonnei (K11) was resistant to $80 \%$ of the antibiotics, although it did not include plasmids, whereas the strain with four plasmids, was only resistant to 10\% of used antibiotics. This can be due to this issue that these plasmids could be cryptic plasmids.

In case of plasmids including E. coli strains, the greater resistance is correlated to the presence of plasmids (40\%), although, one strain (DK2) was resistant to $40 \%$, but did not possess any plasmids (Table 1). Reinthaler et al. (29) reported that $E$. coli strains isolated from treated sewage were less resistant against quinolones. In P. aeruginosa, there was no distinct correlation between plasmids and antibiotic resistance, since some strains had the same plasmid profile, but showed different antibiotic sensitivity (PS12, PS16). In addition, the strains that showed resistance to a greater proportion of antibiotics did not contain plasmids (Table 1, Figure 6).

The strain origin or even the water source does not appear to have a strong effect on the plasmid profile, as shown in Table 1, since strain S. flexneri K4 isolated from ground water at Sohag region, had the same plasmid profile of other seven strains (K1, K2, K5, K6, K7, K10, K9) isolated from Nile water (Table 1). The same can be concluded from the strains of $P$. aeruginosa, since 5 of 7 total strains did not include plasmids, but isolated from different origins. The two strains (PS12, PS16) including the same plasmid profile, were isolated from Nile water but different origins (Sakolta, Dar El-Salam, respectively). This may be due to transfer of these strains during water movement between regions. Several studies proposed that plasmid has a positive correlation with antibiotic resistance. It is believed that the main role of plasmids that encode multiple antibiotic resistances is to confer their hosts the ability to survive in the presence of antimicrobial compounds. As an example in the pathogenic bacterium, Salmonella, plasmids of the incompatibility group HI1 accounted for a significant proportion of antibiotic resistance phenotypes.

Several studies proposed that, plasmids implicated directly in the acquisition of resistance to many antibiotics $(6-12,30)$, which is particularly problematic since plasmids can cross many species and genus barriers, and the rate of plasmid transfer has even been shown to increase in more heterogeneous communities (31). Plasmids allow resistance to spread and persist in niches that are not necessarily subject to antibiotics (13). In Escherichia and Shigella strains, a larger proportion of genome of plasmids codes for antibiotic resistance than that of the chromosome (32). Svara and Rankin (33) revealed that antibiotic resistance genes were significantly overrepresented on plasmids, compared to on the bacterial chromosome. They also documented that environmental variation affects the evolution of plasmid-carried antibiotic resistance. Paytubi et al. (34) concluded that plasmid R27 has a strong impact on the global transcriptome of S. Typhimurium strain SL1344 when cells grow at low temperature and enter the stationary phase.

Although, multiple antibiotic resistance in bacteria is most commonly associated with presence of plasmids, which contain one or more resistance genes, each encoding a single antibiotic resistance phenotype $(8,35)$, some multiple antibiotic resistance are associated with the chromosome (35-38). For example, George and Levy initially described a chromosomal multiple antibiotic resistance system existed in E. coli (39). Resistance genes encoded in plasmids are often located within genetic elements called transposons. These elements include the transposase function that enables the transposon to recombine into the bacterial chromosome or plasmids (40). For this reason, the presence of plasmids in antibiotics resistant organisms is not usually recorded. The plasmid is responsible not only for antibiotic resistance, but also for other jobs, since some plasmid includes genes, which regulate pathogenicity, anaerobic respiration and metabolism determinants, heavy metal resistant. Many attempts were made to solve the antibiotics resistance problems of enteric bacteria generally. For example, Mirnejad et al. (41), identified a Lactobacillus casei strain that strongly inhibits the development of S. sonnei and S. flexneri in vitro.

The acquisition of the mecA gene, which confers resistance to methicillin, spawning so-called methicillin-re- 
sistant S. aureus (MRSA), has resulted in a highly resilient pathogen that reached epidemic levels in many parts of the world (42). All isolated strains had broad-spectrum resistance for all tested antibiotics, especially quinolones (Ciprofloxacin) and B-Lactams (E-moxclav) as shown in Table 1. As shown in Figure 7, all strains had negative results for MRSA-PCR. Our results were in agreement with those obtained by Sekiguchi et al. (43) and Kawai et al. (44).

\section{Acknowledgements}

The authors extend their appreciation to the Deanship of Scientific Research at King Saud University for funding this work through research group no (RG -1435-060).

\section{Authors' Contributions}

Khalid Abdalla Ali Abdel Rahim developed the original idea and the protocol, abstracted and analyzed data, wrote the manuscript and is the guarantor. Ahmed Mohamed Hassanein and Heikal Abd El Hakim Abd El Azeiz contributed to development of the protocol, abstracted data and prepared the manuscript.

\section{Funding/Support}

This project was supported by King Saud University, Deanship of Scientific Research. Research group no.1435060 .

\section{References}

1. World Health Organization.. Overcoming antibiotic resistance. Geneva:WHO; 2000.

2. Lipsitch M, Bergstrom C. Modeling of antibiotic resistance in the ICU - U. S. slant. In: Weinstein RA, Bonten M editors. Infection control in the ICU environment.: Kluwer; 2002.

3. Baquero F, Blazquez J. Evolution of antibiotic resistance. Trends Ecol Evol.1997;12(12):482-7.

4. Lipsitch M, Samore MH. Antimicrobial use and antimicrobial resistance: a population perspective. Emerg Infect Dis. 2002;8(4):347-54

5. Thomas CM, Nielsen KM. Mechanisms of, and barriers to, horizontal gene transfer between bacteria. Nat Rev Microbiol. 2005;3(9):711-21.

6. Falkow S, Citarella RV, Wohlhieter JA. The molecular nature of Rfactors. J Mol Biol.1966;17(1):102-16.

7. Sugino Y, Hirota Y. Conjugal fertility associated with resistance factor R in Escherichia coli. J Bacteriol. 1962;84:902-10.

8. Clewell DB, Yagi Y, Bauer B. Plasmid-determined tetracycline resistance in Streptococcus faecalis: evidence for gene amplification during growth in presence of tetracycline. Proc Natl Acad Sci US A. 1975;72(5):1720-4.

9. Livermore DM. beta-Lactamases in laboratory and clinical resistance. Clin Microbiol Rev.1995;8(4):557-84.

10. Johnsen PJ, Simonsen GS, Olsvik O, Midtvedt T, Sundsfjord A Stability, persistence, and evolution of plasmid-encoded VanA glycopeptide resistance in enterococci in the absence of antibiotic selection in vitro and in gnotobiotic mice. Microb Drug Resist. 2002;8(3):161-70.

11. Weigel LM, Clewell DB, Gill SR, Clark NC, McDougal LK, Flannagan $\mathrm{SE}$, et al. Genetic analysis of a high-level vancomycin-resistant isolate of Staphylococcus aureus. Science. 2003;302(5650):1569-71.

12. Furuya EY, Lowy FD. Antimicrobial-resistant bacteria in the community setting. Nat Rev Microbiol. 2006;4(1):36-45.
13. Hughes VM, Datta N. Conjugative plasmids in bacteria of the 'pre-antibiotic' era. Nature. 1983;302(5910):725-6.

14. Kruse $\mathrm{H}$, Sorum $\mathrm{H}$. Transfer of multiple drug resistance plasmid between bacteria of diverse origins in natural microenvironments. Appl Environ Microbiol.1994;60(11):4015-21.

15. Mach PA, Grimes DJ. R-plasmid transfer in a wastewater treatment plant. Appl Environ Microbiol. 1982;44(6):1395-403.

16. Murakami K, Minamide W, Wada K, Nakamura E, Teraoka $\mathrm{H}$, Watanabe S. Identification of methicillin-resistant strains of staphylococci by polymerase chain reaction. J Clin Microbiol. 1991;29(10):2240-4.

17. Ubukata K, Nonoguchi R, Song MD, Matsuhashi M, Konno M. Homology of mecA gene in methicillin-resistant Staphylococcus haemolyticus and Staphylococcus simulans to that of Staphylococcus aureus. Antimicrob Agents Chemother. 1990;34(1):170-2.

18. Holt JG, Krieg NR, Sneath PHA, Staley JT, Williams ST. Bergey's manual of determinative bacteriology.Baltimore: Williams and Wilkins; 1994.

19. Kiska D, Gilligan P. Manual of clinical microbiology. 7 ed. Murray B editor. Washington, D.C.: American Society for Microbiology; 1999.

20. Tajima A, Sakurai K, Minamiyama M. Behavior of pathogenic microbes in a treated wastewater reuse system and examination of new standards for the reuse of treated wastewater. Environ Monit Assess. 2007;129(1-3):43-51.

21. Bauer AW, Kirby WM, Sherris JC, Turck M. Antibiotic susceptibility testing by a standardized single disk method. Am J Clin Pathol. 1966;45(4):493-6.

22. Maloy SR. Experimental techniques in bacterial genetics.: Jones \& Bartlett Learning; 1990

23. Birnboim HC. A rapid alkaline extraction method for the isolation of plasmid DNA. Methods Enzymol. 1983;100:243-55.

24. Towner KJ, Talbot DC, Curran R, Webster CA, Humphreys H. Development and evaluation of a PCR-based immunoassay for the rapid detection of methicillin-resistant Staphylococcus aureus.J Med Microbiol.1998;47(7):607-13.

25. Kollef MH. Gram-negative bacterial resistance: evolving patterns and treatment paradigms. Clin Infect Dis. 2005;40 Suppl 2:S85-8.

26. Djahmi N, Dunyach-Remy C, Pantel A, Dekhil M, Sotto A, Lavigne JP. Epidemiology of carbapenemase-producing Enterobacteriaceae and Acinetobacter baumannii in Mediterranean countries. Biomed Res Int. 2014;2014:305784.

27. Hsu CH, Hwang SC, Liu JK. Succession of bacterial drug resistance as an indicator of antibiotic application in aquaculture. J Fish Soc. 1992;19(1):55-64.

28. Dale J, Park S. Molecular Genetics of Bacteria. 4 edChichester: John Wiley \& Sons Inc.; 2004.

29. Reinthaler FF, Posch J, Feierl G, Wust G, Haas D, Ruckenbauer G, et al. Antibiotic resistance of E. coli in sewage and sludge. Water Res. 2003;37(8):1685-90

30. Robicsek A, Jacoby GA, Hooper DC. The worldwide emergence of plasmid-mediated quinolone resistance. Lancet Infect Dis. 2006;6(10):629-40.

31. Dionisio F, Matic I, Radman M, Rodrigues OR, Taddei F. Plasmids spread very fast in heterogeneous bacterial communities. Genetics. 2002;162(4):1525-32.

32. Turner P, Cooper V, Lenski R. Tradeoff Between Horizontal and Vertical Modes of Transmission in Bacterial Plasmids. Evolution. 1998;52(2):315.

33. Svara F, Rankin DJ. The evolution of plasmid-carried antibiotic resistance. BMC Evol Biol. 2011;11:130.

34. Paytubi S, Aznar S, Madrid C, Balsalobre C, Dillon SC, Dorman CJ, et al. A novel role for antibiotic resistance plasmids in facilitating Salmonella adaptation to non-host environments. Environ Microbiol. 2014;16(4):950-62.

35. Foster TJ. Plasmid-determined resistance to antimicrobial drugs and toxic metal ions in bacteria. Microbiol Rev.1983;47(3):361-409.

36. Johnson SR, Morse SA. Antibiotic resistance in Neisseria gonorrhoeae: genetics and mechanisms of resistance. Sex Transm Dis. 1988;15(4):217-24.

37. Sanders CC, Sanders WJ, Goering RV, Werner V. Selection of multiple antibiotic resistance by quinolones, beta-lactams, 


\section{AbdelRahim KAA et al.}

and aminoglycosides with special reference to cross-resistance between unrelated drug classes. Antimicrob Agents Chemother 1984;26(6):797-801.

38. Then RL, Angehrn P. Multiply resistant mutants of Enterobacter cloacae selected by beta-lactam antibiotics. Antimicrob Agents Chemother.1986;30(5):684-8.

39. George AM, Levy SB. Amplifiable resistance to tetracycline, chloramphenicol, and other antibiotics in Escherichia coli: involvement of a non-plasmid-determined efflux of tetracycline. J Bacteriol.1983;155(2):531-40.

40. Carattoli A. Plasmid-mediated antimicrobial resistance in Salmonella enterica. Curr Issues Mol Biol. 2003;5(4):113-22.

41. Mirnejad R, Vahdati AR, Rashidiani J, Erfani M, Piranfar V. The antimicrobial effect of lactobacillus casei culture supernatant against multiple drug resistant clinical isolates of Shigella sonnei and Shigella flexneri in vitro. Iran Red Crescent Med J. 2013;15(2):122-6.

42. Rennie RP, Jones RN, Mutnick AH, Sentry Program Study Group Occurrence and antimicrobial susceptibility patterns of pathogens isolated from skin and soft tissue infections: report from the SENTRY Antimicrobial Surveillance Program (United States and Canada, 2000). Diagn Microbiol Infect Dis. 2003;45(4):287-93.

43. Sekiguchi J, Hama T, Fujino T, Araake M, Irie A, Saruta K, et al. Detection of the antiseptic-and disinfectant-resistance genes qacA qacB, and qacC in methicillin-resistant Staphylococcus aureus isolated in a Tokyo hospital.Jpn J Infect Dis. 2004;57(6):288-91.

44. Kawai M, Yamada S, Ishidoshiro A, Oyamada Y, Ito H, Yamagishi J. Cell-wall thickness: possible mechanism of acriflavine resistance in meticillin-resistant Staphylococcus aureus. J Med Microbiol. 2009;58(Pt 3):331-6. 